\title{
Statistical Investigation of the Effects of Fetal Heart Rate (FHR) and Uterine Contractions (UC) Signals on Apgar
}

\author{
Barış Doruk Güngör \\ Faculty of Technology, Biomedical Engineering \\ Kocaeli University \\ Kocaeli, Turkey
}

\begin{abstract}
Apgar scoring is a method which is a fast and an effective way of understanding whether newborn babies are healthy or not. Any intervention to the baby such as resuscitation or intubation is done, if necessary, after evaluating the Apgar score and examining various physiological data. Shortening the response time for medical support is vitally important for babies. In this study, the physiological data gathered from mother and fetus along with the features extracted from FHR (fetal heart rate) and UC (uterus contraction) signals were examined in order to determine whether the newborn will have any immediate problems that will need medical support before the baby was actually born and a study towards Apgar scoring was made. There were two classes (intervention, nonintervention) used in this study. Data was analyzed by using Mann-Whitney U test. The classes were compared in terms of statistical data, FHR and UC signals and according to the obtained the results, intervention and non-intervention classes have been shown to have a significant difference for 5 extracted features. However, no significant changes have been detected in other features.
\end{abstract}

\section{Keywords}

Apgar Score; Cardiotocography; Fetal Heart Rate (FHR); Uterine Contraction (UC); Mann-Whitney U Test.

\section{INTRODUCTION}

The initial assessment of the newborn right after birth is quite important. Whether the baby needs any intervention should be determined within seconds. For this purpose, it would be a great advantage to know whether the baby needs any postnatal intervention (resuscitation or intubation) before birth. Assessing the patients by scoring over general findings is a widely used method. The method of scoring used for the newborn is called the Apgar Score [1].

\subsection{Apgar Score}

The Apgar score is a simple and repeatable method used to assess the health of the newborn quickly and briefly right after birth. The Apgar scoring was developed in order to detect the effect of obstetric anaesthesia on babies, and is quite important for the neurologic development of the baby. The newborn are assessed within the scale between 0 and 2 for 5 different criteria, and the sum of the relevant values determines the apgar score of the baby between 0 and 10 . The baby is applied the apgar scoring twice right after birth (at the first and fifth minutes). While a score of 8 and above is normal according to apgar scoring; for a score of 7 and below, interventions such as resuscitation (basic life support, bringing back to life) or intubation (opening of the artificial airway, providing the first breathing using tube) are applied on the babies [1] [2].

While there are studies related to the use of the FHR signal in the prediction of the diseases such as foetal acidosis (acid

\author{
Muhammed Kürşad Uçar, Ferda Bozkurt \\ Faculty of Engineering, Electrical and Electronics \\ Engineering \\ Sakarya University \\ Sakarya, Turkey
}

poisoning), asphyxia (lack of oxygen) and hypoxia (decreased oxygen levels in the body) requiring resuscitation, using the FHR and UC signals for the determination of Apgar score by examining the physiological data as well is a new approach [2] [3] [4] [5].

\subsection{Factors of Apgar Score}

5 criteria taken into consideration in Apgar scoring are as follows.

\subsubsection{Appearance/Complexion (Skin Colour)}

The newborn are generally cyanotic (the appearance of a blue coloration of the skin or mucous membranes) due to low oxygen intake despite their capacity to carry high oxygen. Many children show cyanotic hand and foot symptoms for a few minutes despite excellent ventilation and oxygen supplementation. At the stage of scoring, 2 points are given when the hands, feet and body of the baby are pink; 1 point is given when there is acrocyanosis (cyanotic state of the hands and feet) while the body is pink; and 0 is given when the whole body of the baby is of bluish or purple colour.

\subsubsection{Pulse (Heart Apex Beat)}

2 points are given when the baby's heart beat rate is 100 and above; 1 point is given when it is below 100; and 0 is given when there is no heart beat at all.

\subsubsection{Grimace (Response to Stimulus)}

When oropharynx, or aspiration using a soft rubber catheter on the nostrils is applied (the mechanical cleansing of the mouth and nose of the baby), 2 points are given if the baby exhibits one of the responses of crying, sneezing, coughing or pulling itself back; 1 point is given if it makes a grimace or cries weakly; and 0 is given if it does not respond at all.

\subsubsection{Activity (Muscular Tonus)}

2 points are given to the babies whose body strength is good and flex their arms and legs on their own; 1 point is given to those who can bend them a bit; and 0 is given to those who fail to exhibit any resistance.

\subsubsection{Respiration}

2 points are given to the babies exhibiting normal respiration and crying heavily in the 60 seconds following birth; 1 point is given to those who breathe weekly and irregularly; and 0 is given to those who are apnoeic (cessation of the baby's breathing)

Looking at the apgar scoring, it can be decided whether the newborn baby needs any intervention. In this study, it is aimed to determine whether the baby would need any intervention using certain physiological data, FHR and UC signals prenatally. By this means, it will be possible to determine the situations that may require intervention before making apgar scoring, whereby the intervention time will be minimized and any physical damage to the baby can be 
prevented. As a result of the study, the efficiency of the system will be checked by comparing the result of whether intervention is required or not required obtained prenatally with the post-natal apgar scoring.

\section{MATERIAL AND METHOD}

\subsection{Data Collection}

The database used in the study contains 132 carefully selected cardiotocography (CTG) records of 9164 records collected in Czech Technical University (CTU) and University Hospital Brono (UHB) between 2010 and 2012; and all records were taken from Physionet [3]. The CTG data consist of records that were started to be recorded 90 minutes before birth, which are no longer than 90 minutes in length. Each CTG record contains foetal heart beat rates and uterine contraction signal exemplified in $4 \mathrm{~Hz}$. Only the patient records that fulfil below criteria were used in order to create as homogenous a series as possible.

\subsubsection{Factors Considerations in Patient Records}

The assessment of the CTG data were made by 9 obstetricians looking at the variability and reliability signals for each signal, and sticking to the explanations of the signals (following the FIGO instructions used in Czech Republic).

Only patient records providing the following criteria are used to create a homogeneous array as possible.

- $\quad$ Singleton pregnancy

- Gestation period > 36 weeks

- Developmental defects previously unknown

- $\quad$ Second level labour time $\leq 30$ minutes

- Quality of the FHR signal (percentage of record, when FHR data are appropriate) $>50 \%$ of each 30 minute period

- Having a blood gas analysis taken from umbilical artery

- Vaginal (normal) birth majority (only includes 46 caesarean deliveries)

Additional parameters collected from all records;

- Maternal data; the age of the mother, number of deliveries and pregnancies

- Birth data; type of birth (vaginal delivery and caesarean delivery), duration of delivery, fluid meconium, measurement type (ultrasound or direct cranial ultrasound)

- Foetal data; gender and birth weight

- Data of the newborn; analysis of the arterial blood sample (ph, pCO_2, pO_2, base deficit and calculated BDecf), apgar scoring, neonatalogic assessment (O2 need, seizures, entry into the newborn intensive care unit (NICU)

\subsection{Properties of FHR and UC Signals}

Data used in the study were started to be recorded 90 minutes before the birth. 10 properties were extracted from FHR and UC signals exemplified in $4 \mathrm{~Hz}$ in time space. These properties were started to be tested using Mann-Whitney U test, and it was endeavoured to determine whether there is a significant difference between them. The properties extracted from FHR and UC signals in time space are as follows:
1. Standard deviation [4] [5] [6]

2. Maximum value [7]

3. Coefficient of skewness [8] [9] [10] [11]

4. Coefficient of kurtosis [4] [10] [11]

5. Shape factor [12]

6. Variance [13] [14] [5] [6]

7. Hjorth activity parameter [15] [16]

8. Hjorth complexity parameter [15] [16]

9. Average curve length [17]

10. Average teager energy [17]
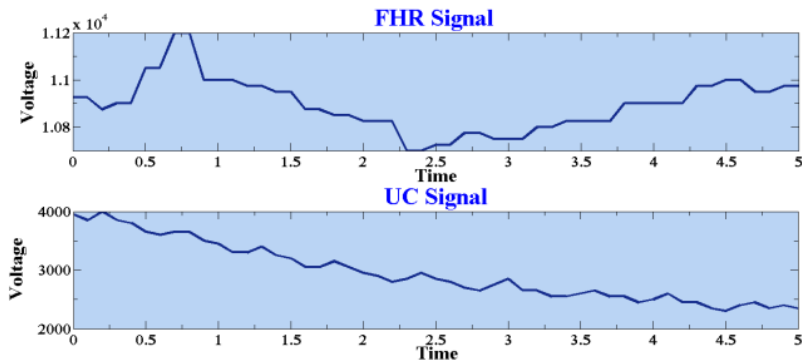

Fig. 1: Exemplary FHR and UC signals

\subsection{Properties of Statistical Data}

The title (Helvetica 18-point bold), authors' names (Helvetica 12-point) and affiliations (Helvetica 10-point) run across the full width of the page - one column wide. We also recommend e-mail address (Helvetica 12-point). See the top of this page for three addresses. If only one address is needed, center all address text. For two addresses, use two centered tabs, and so on. For three authors, you may have to improvise.

\subsubsection{Foetal Information}

11. Week of gestation: Indicates how many weeks old the baby is.

12. Weight of the baby $(\mathrm{g})$ : Indicates the prenatal weight of the foetus.

13. Gender: Indicates the sex of the baby.

\subsubsection{Maternal Risk Factors}

14. Age: Indicates the age of the mother.

15. Gravidity: Indicates the number of pregnancy.

16. Parity: Indicates the number of birth.

17. Diabetes: A metabolic disorder occurring due to an increase in glucose levels in the blood under the influence of genetic and environmental factors.

18. Hypertension: A chronic condition occurring as a result of the rise of blood pressure in the arteries.

19. Preeclampsia: A complication that occurs in the presence of hypertension, high amounts of protein in the urine and toxic effects in the second half of pregnancy.

20. Liquid Precocious: Discharge of the amniotic fluid in the form of vaginal discharge as a result of the premature rupture of the amniotic membrane.

21. Hyperpyrexia: Elevation of body temperature. 
22. Meconium: First stool of the foetus.

\subsubsection{Birth Information}

23. Presentation: Indicates the position of the baby's arrival during childbirth.

24. Induced labour: Indicates starting of the birth using stimuli such as artificial birth pain or drug.

25. $2^{\text {nd }}$ Stage: Indicates the period from the full opening of the cervix to the birth of the baby.

26. Birth type: Indicates whether the birth is normal birth or caesarean birth.

\subsection{Mann-Whitney U Test}

The data set used in the study consists of a single group and two classes. First, the normality test was applied on the data set. Shapiro-Wilk table was examined as the number of the data used is above 50. As a result, it was seen that the distribution for 26 data used in the study is not normal distribution. Data used are ordered and consist of independent groups, however they are not parametric. This is the reason why the study was conducted using the SPSS (Statistical Package for the Social Sciences) program. As the Apgar score is an ordering data type, Mann-Whitney $U$ test was chosen as the suitable analysis method. Mann-Whitney U test is a nonparametric statistical test used to examine whether two samples come from the same distribution. According to this test, data with a p-value that is lower than 0.05 are statistically significant, while those greater than 0.05 are statistically insignificant [4].

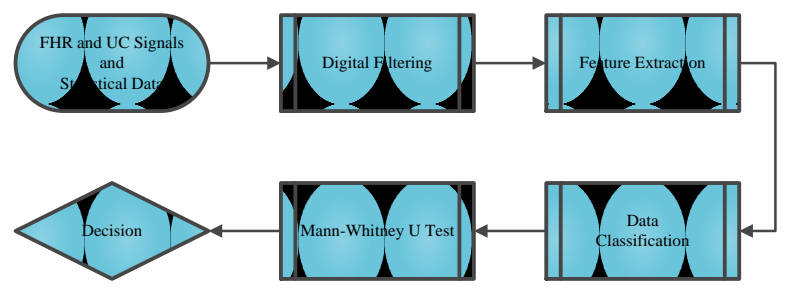

Fig 2. Exemplary FHR and UC signals

\section{RESULTS}

The steps of the process were fulfilled in line with the flow chart in figure 2, and the results obtained in accordance with Mann-Whitney $U$ test were given in table 1 , table 2 and table 3 .

Means, standard deviations and $\mathrm{p}$ values of the data pertaining to FHR signals are shown in table 1.

Means, standard deviations and $\mathrm{p}$ values of the data pertaining to UC signals are shown in table 2 .

While the properties in table 1 do not constitute a significant difference in terms of p-values, only the 9th property constitutes a significant difference in table 2 . That the $p$ value is lower than 0.004 means that this property is statistically significant and can be used in classification.

The mean, standard deviation and $\mathrm{p}$ values of the data related to foetus information, maternal risk factors and birth information are shown in table 3 . In the light of the results in Table 3, it is seen that the $\mathrm{p}$ values of the properties no. 12, 13,16 and 25 are lower than 0.05 . Thus, the two classes called "requires intervention" and "does not require intervention" can be differentiated as two different classes in terms of these properties.
5 properties of the 26 properties extracted as a result of this study are statistically significant. These properties are the properties no. 12, 13, 16 and 25 related to foetus information, maternal risk factors and birth information; and property no. 9 extracted for the UC signal. There is a significant difference between the two classes in terms of these properties. When the properties no. 12, 13, 16, 25 used in the study and the property no. 9 extracted for the UC signal are used for the determination of the apgar score, it will provide a great ease in terms of establishing whether the babies require any post-natal intervention (resuscitation or incubation) before birth. This will reduce the intervention period, whereby minimising the foetal and neonatal deaths.

In future studies, new analyses can be conducted using different features to be obtained from FHR and UC signals.

Table 1. Means, standard deviations and $p$ values of FHR signals

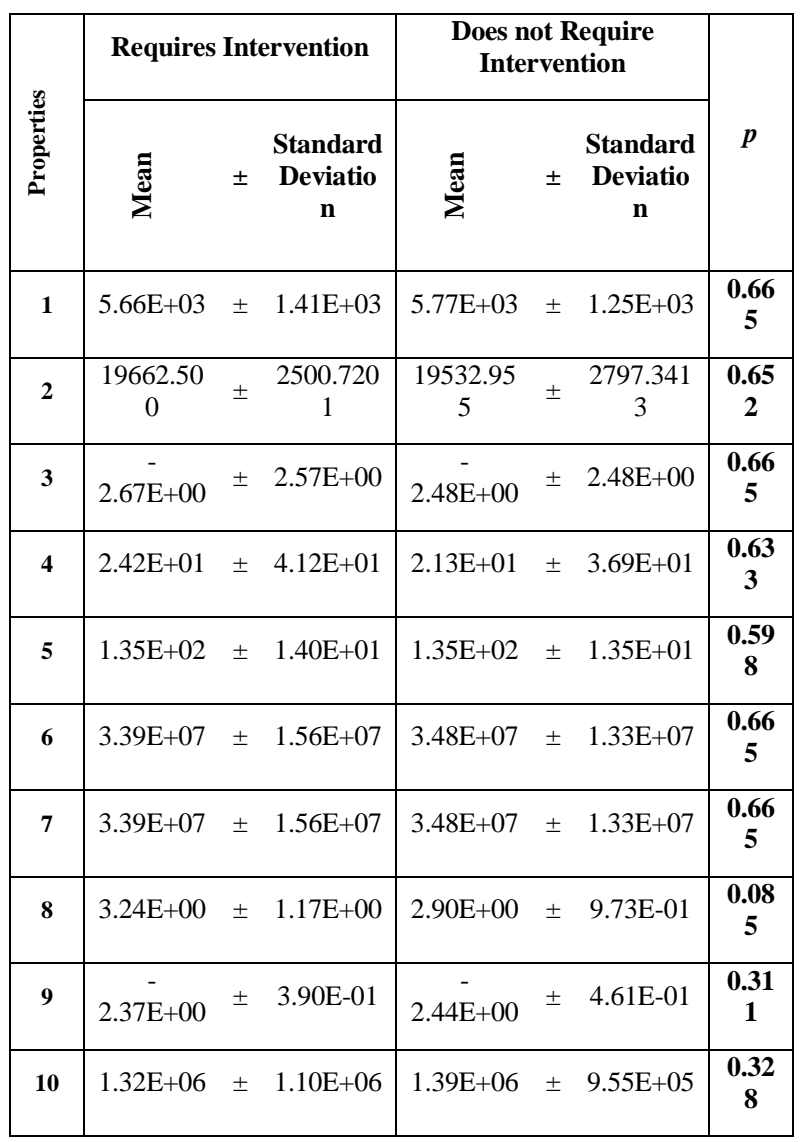

Table 2. Means, standard deviations and p values of UC signals

\begin{tabular}{|c|c|c|c|c|c|c|c|}
\hline \multirow{2}{*}{ : } & \multicolumn{3}{|c|}{ Requires Intervention } & \multicolumn{3}{|c|}{$\begin{array}{l}\text { Does not Require } \\
\text { Intervention }\end{array}$} & \multirow[b]{2}{*}{$p$} \\
\hline & 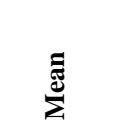 & \pm & $\begin{array}{l}\text { Standard } \\
\text { Deviatio } \\
\text { n }\end{array}$ & $\stackrel{\text { Eี }}{\text { Е }}$ & \pm & $\begin{array}{l}\text { Standard } \\
\text { Deviatio } \\
\text { n }\end{array}$ & \\
\hline 1 & $2.47 \mathrm{E}+03$ & \pm & $7.77 \mathrm{E}+02$ & $2.44 \mathrm{E}+03$ & \pm & $6.03 \mathrm{E}+02$ & $\begin{array}{c}0.87 \\
7\end{array}$ \\
\hline 2 & 9899.242 & \pm & $\begin{array}{c}2794.988 \\
5\end{array}$ & $\begin{array}{c}10020.45 \\
5\end{array}$ & \pm & $\begin{array}{c}2698.018 \\
9\end{array}$ & $\begin{array}{c}0.82 \\
2\end{array}$ \\
\hline 3 & - & \pm & $5.12 \mathrm{E}+00$ & & \pm & $5.19 \mathrm{E}+00$ & 0.80 \\
\hline
\end{tabular}




\begin{tabular}{|c|c|c|c|}
\hline & $6.33 \mathrm{E}+00$ & $6.61 \mathrm{E}+00$ & 6 \\
\hline 4 & $1.21 \mathrm{E}+02 \pm 1.05 \mathrm{E}+02$ & $1.22 \mathrm{E}+02 \pm 9.98 \mathrm{E}+01$ & $\begin{array}{c}0.79 \\
9\end{array}$ \\
\hline 5 & $9.38 \mathrm{E}+01 \pm 2.24 \mathrm{E}+01$ & $1.01 \mathrm{E}+02 \pm 6.31 \mathrm{E}+01$ & $\begin{array}{c}0.91 \\
7\end{array}$ \\
\hline 6 & $6.72 \mathrm{E}+06 \pm 5.09 \mathrm{E}+06$ & $6.33 \mathrm{E}+06 \pm 3.09 \mathrm{E}+06$ & $\begin{array}{c}0.87 \\
7\end{array}$ \\
\hline 7 & $6.72 \mathrm{E}+06 \pm 5.09 \mathrm{E}+06$ & $6.33 \mathrm{E}+06 \pm 3.09 \mathrm{E}+06$ & $\begin{array}{c}0.87 \\
7\end{array}$ \\
\hline 8 & $6.63 \mathrm{E}+00 \pm 2.29 \mathrm{E}+00$ & $6.24 \mathrm{E}+00 \pm 1.95 \mathrm{E}+00$ & $\begin{array}{c}0.51 \\
8\end{array}$ \\
\hline 9 & $\stackrel{-}{-}+89 \mathrm{E}+00 \pm 2.00 \mathrm{E}-01$ & $2.01 \mathrm{E}+00 \pm 2.23 \mathrm{E}-01$ & $\begin{array}{c}0.00 \\
1\end{array}$ \\
\hline 10 & $1.25 \mathrm{E}+05 \pm 2.25 \mathrm{E}+05$ & $8.58 \mathrm{E}+04 \pm 2.71 \mathrm{E}+04$ & $\begin{array}{c}0.19 \\
3\end{array}$ \\
\hline
\end{tabular}

Table 3. Means, standard deviations and $p$ values of the statistical data

\begin{tabular}{|c|c|c|c|c|c|c|c|}
\hline \multirow{2}{*}{ 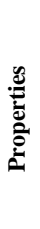 } & \multicolumn{3}{|c|}{ Requires Intervention } & \multicolumn{3}{|c|}{$\begin{array}{l}\text { Does not Require } \\
\text { Intervention }\end{array}$} & \multirow{2}{*}{$p$} \\
\hline & $\stackrel{\mathrm{E}}{\mathrm{E}}^{\mathrm{E}}$ & \pm & $\begin{array}{l}\text { Standard } \\
\text { Deviation }\end{array}$ & $\sum^{\tilde{\Sigma}}$ & \pm & $\begin{array}{l}\text { Standard } \\
\text { Deviation }\end{array}$ & \\
\hline 11 & 39.788 & \pm & 1.1302 & 84.015 & \pm & 358.2072 & 0.702 \\
\hline 12 & 3441.364 & \pm & 443.0589 & 3243.591 & \pm & 626.4837 & 0.044 \\
\hline 13 & 1.348 & 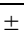 & 0.4801 & 2.000 & - & 3.6585 & 0.013 \\
\hline 14 & 28.758 & \pm & 5.5666 & 30.091 & \pm & 5.9271 & 0.077 \\
\hline 15 & 1.242 & \pm & 0.7455 & 1.530 & \pm & 1.0985 & 0.060 \\
\hline 16 & 0.227 & \pm & 0.4573 & 0.591 & \pm & 0.7437 & 0.002 \\
\hline 17 & 0.045 & \pm & 0.2099 & 0.091 & \pm & 0.2897 & 0.302 \\
\hline 18 & 0.091 & \pm & 0.2897 & 0.045 & \pm & 0.2099 & 0.302 \\
\hline 19 & 0.076 & \pm & 0.2666 & 0.030 & \pm & 0.1727 & 0.246 \\
\hline 20 & 0.273 & \pm & 0.4488 & 0.288 & \pm & 0.4562 & 0.847 \\
\hline 21 & 0.000 & \pm & 0.0000 & 0.000 & \pm & 0.0000 & 1.000 \\
\hline 22 & 0.106 & \pm & 0.3103 & 0.030 & \pm & 0.1727 & 0.085 \\
\hline 23 & 1.212 & \pm & 0.5411 & 1.167 & \pm & 0.5430 & 0.339 \\
\hline 24 & 0.333 & \pm & 0.4750 & 0.379 & \pm & 0.4888 & 0.587 \\
\hline 25 & 13.727 & \pm & 8.5459 & 8.545 & \pm & 7.5165 & 0.000 \\
\hline 26 & 1.152 & \pm & 0.3613 & 1.197 & \pm & 0.4008 & 0.493 \\
\hline
\end{tabular}

\section{REFERENCES}

[1] N. Comart, Elektronik Fetal Kalp Hızı Monitörizasyonu: Normal Monitör, Fetal Stres, Fetal Distres ile İlişkili Erken Neonatal Sonuçlar, İstanbul, 2006.

[2] N. Çiçek, C. Akyürek, Ç. Çelik and A. Haberal, Kadın Hastalıkları ve Doğum Bilgisi, İstanbul, 2006.

[3] A. Goldberger, L. Amaral, L. Glass, J. Hausdorff, P. Ivanov, R. Mark, J. Mietus, G. Moody, C.-K. Peng and H. Stanley, "The CTU-UHB Intrapartum Cardiotocography Database," PhysioBank, PhysioToolkit, and PhysioNet: Components of a New
Research Resource for Complex Physiologic Signals, vol. 101, no. 23, pp. e215-e220, 2000.

[4] R. Alpar, Uygulamalı İstatistik ve Geçerlik-Güvenilirlik, Ankara: Detay Yayıncılık, 2012.

[5] J. M. Bland and D. G. Altman, "Measurement Error," Biomedical Journal, no. 312, 1996.

[6] S. Gorard, "Revisiting a 90-Year-Old Debate: The Advantages of The Mean Deviation," in British Educational Research Association Annual Conference, 2004.

[6] S. Gorard, "Revisiting a 90-Year-Old Debate: The Advantages of The Mean Deviation," in British Educational Research Association Annual Conference, 2004.

[8] R. A. Groeneveld and G. Meeden, "Measuring Skewness and Kurtosi," The Statistician, no. 33, pp. 391-399, 1984.

[9] P. T. Hippel, "Mean, Median, and Skew: Correcting a Textbook Rule," Journal os Statistic Education, no. 13, 2005.

[10] S. Brown, Measures of Shape: Skewness and Kurtosis, Tompkins Cortland Community College, 2008.

[11] Ç. Arıkan and M. Özdemir, "Bazı Güç Kalitesi Bozunumlarının Belirlenmesinde Çarpıklık ve Basıklık Katsayıları İle Dalgacık Katsayılarından Enerji Yöntemiyle Özellik Çıkarımı Yönteminin Karşılaștırılması," in V.ENERJI VERİMLİLİ̆̇̇ VE KALITESİ SEMPOZYUMU, Kocaeli, 2013.

[12] J. Fu, N. Li, L. Li, R. Luo and Q. Zhou, The Obtainment of Particle Shape Factor by the Combination of Experimental Data and Fluid-particle Reaction Model, Powder Technology, 2015.

[13] Ş. Bülbül, Tanımlayıcı İstatistik, İstanbul: Der Yayınları, 2000.

[14] N. Çömlekçi, Temel İstatistik İlke ve Teknikleri, Bilim Teknik Yayınevi, 1994.

[15] M. Yıldız, Uyku Evrelerinin EEG İşaretleri Kullanılarak Sınıflandırılmasında Yeni Bir Yaklaşım, Sakarya Üviversitesi, Fen Bilimleri Enstitüsü, 2009.

[16] M. Vourkas, G. Papadourakis and S. Micheloyannis, "Use of ANN and," 1st International, pp. 327-332, 2000.

[17] E. Avşar, Tek-Sınıf Destek Vektör Makineleri Kullanılarak Epileptik EEG İsaretlerinin Sınıflandırılması, İstanbul Üniversitesi, Fen Bilimleri Enstitüsü, 2009.

[18] V. Apgar, "A Proposal for a New Method of Evaluation of the Newborn Infant," Current Researches in Anesthesia and Analgesia, July-August 1953.

[19] V. Chudacek, J. Spilka, P. Janku, M. Koucky, L. Lhotska and M. Huptych, "Automatic Evaluation of Intrapartum Fetal Heart Rate Recordings: a Comprehensive Analysis of Useful Features," IOPscience, no. 32, pp. 1347-1360, 2011. 
[20] A. Georgieva, S. J. Payne, M. Moulden and C. W. G. Redman, "Artificial Neural Networks Applied to Fetal Monitoring in Labour," Neural Computing and Applications, no. 22, pp. 85-93, 2013.

[20] A. Georgieva, S. J. Payne, M. Moulden and C. W. G. Redman, "Artificial Neural Networks Applied to Fetal Monitoring in Labour," Neural Computing and Applications, no. 22, pp. 85-93, 2013.
[21] M. Jezewski, R. Czabanski, J. Wrobel and K. Horoba, "Analysis of Extracted Cardiotocographic Signal Features to Improve Automated Prediction of Fetal Outcome," Biocybernetics and Biomedical Engineering, vol. 30, no. 4, pp. 29-47, 2010.

[22] M. Köseoğlu and R. Yamak, Uygulamalı İstatistik ve Ekonometri, Trabzon: Celepler Matbaacilık, 2004. 